\section{Hate Speech, Agama, dan Kontestasi Politik di Indonesia}

\section{Winda Wana Utami}

Universitas Islam Negeri Imam Bonjol Padang, Indonesia windaut9@gamil.com

\section{Darmaiza}

Universitas Islam Negeri Imam Bonjol Padang, Indonesia darmaizaza@gmail.com
Indonesian Journal of Religion and Society, 2020, Vol. 02 (02), 113-128

(C) The Journal, 2020

DOI: $10.36256 /$ ijrs.v2i2. 108

$\underline{\text { www.journal.lasigo.org/index.php/IJRS }}$

aches

Journal

Article History

Received: October $11^{\text {th }}, 2020$

Revised: December 20th 2020

Accepted: December 23rd, 2020

\begin{abstract}
ABSTRAK
Studi ini bertujuan untuk menjelaskan tipe-tipe hate speech di Facebook dan Instagram terkait dengan kontestasi politik Joko Widodo sebagai Presiden tahun 2014, calon Presiden tahun 2019, dan Basuki Tjahaja Purnama Gubernur DKI Jakarta tahun 2017. Penelitian ini menggunakan pendekatan content analisis. Studi ini menemukan beberapa tipe yang dapat dikategorikan kepada hatespeech yaitu dalam bentuk sindiran/sarkasme, hoax, makian, distorsi, cacian, kritik negatif. Orientasi yang digunakan pada momen politik berkaitan dengan agama berkenaan dengan ideologi keagamaan. Istilah keagamaan dijadikan sebagai ripertoir untuk memobilisasi, dan isu SARA digunakan sebagai alat menekankan lawan Politik. Studi ini menyimpulkan tren kontestasi politik dewasa ini berkait-kelindan dengan meningkatnya politik identitas, agama, dan hatespeech sebagai wujud demokrasi tanpa moral.
\end{abstract}

Kata Kunci: Hatespeech, Agama, Kontestasi Politik.

\title{
ABSTRACT
}

The aim of this study is to explain the types of hate speech on Facebook and Instagram related to the political contestation of Joko Widodo as President in 2014, presidential candidate in 2019, and Basuki Tjahaja Purnama, Governor of DKI Jakarta in 2017. This research uses a content analysis approach. The result of study found several types that can be categorized as hatespeech, namely in the form of satire/sarcasm, hoaxs, cursing, distortion, insults, and negative criticism. The orientation that used in political moments is related to religion with regard to religious ideology. The term religion is used as a ripertoir for mobilizing, and the issue of ethnic, religion, race and groups (SARA) is used as a means of emphasizing political opponents. This study concludes that the current trend of political contestation is intertwined with the increasing politics of identity, religion and hatespeech as a form of democracy without morals.

Kata Kunci: Hate Speech, Religion, Political Conterstaion.

\section{Pendahuluan}

Studi ini fokus kepada analisis ujaran kebencian bernuasa agama di media sosial pada momen politik tahun 2014, 2017, 2019 di media sosial, baik itu dalam bentuk perkataan 
yang menghujat atau menjatuhkan antara satu sama agama dengan agama lainnya, etnik, dan ras. Ujaran kebencian atau hate speech menjadi salah satu 'tantangan' serius bagi proses demokrasi di Indonesia sejak 1998. Keterbukaan Politik menentukan bentuk dan tulisan dengan pesan yang beragam termasuk narasi-narasi yang mendorong permusuhan terhadap kelompok lain yang berbeda. Ujaran kebencian tidak jarang dikaitkan dengan terjadinya banyak tindak kekerasan terhadap kelompok agama minoritas. Tuntutan pemerintah supaya bersikap tegas terhadap ujaran kebencianpun semakin terdengar sederhana. Beberapa pihak, menghawatirkan penegakan hukum terhadap ujaran kebencian repsensi yang sering masa lalu, di mana isu SARA dan agama digunakan untuk alat menekankan lawan Politik (Ahnaf \& Suhadi, 2014; Irawan, 2018).

Studi ini didesain untuk melihat apa saja tipe-tipe serta konten dan orientasi yang berkaitan dengan hate Speech pada kontestasi politik di Indonesia pada tahun 2014, 2017, 2019. Pendapat dan kreasi di media sosial khususnya facebook dan instragram disampaikan secara tidak langsung, namun para pengguna media sosial sendiri tidak sadar hal yang dilakukan itu melanggar norma atau tidak, meresahkan atau tidak melanggar hak asasi orang lain benar atau tidak (lihat juga Umroh, 2019), sehingga diperlukan pengelompokan berdasarkan tipe atau jenis ujaran kebencian di facebook dan instragram baik itu dalam pengelompokan agama, ras, suku dan bangsa atau kata-kata komentar yang di tulis dalam facebook dan instagram. Lebih tepatnya melihat bagaimana ujaran kebencian pada masa kampanye di tahun 2014 dalam pemilihan presiden yang di khususkan ujaran kebencian kepada Joko Widodo, serta bagaimana ujaran kebencian yang kepada salah satu tokoh calon gubernur DKI jakarta pada tahun 2017 yaitu Basuki Tjahaja Purnama atau yang di kenal sebagai Ahok, dan yang terakhir adalah pada tahun 2019 yang merupakan bagian dari pemilihan umum serentak pertama kali di Indonesia. Juga, ujaran kebencian kepada Joko Widodo selaku presiden waktu itu dan sebagai calon presiden pada tahun 2019-2024. Agama yang dianut oleh mayoritas muslim di Indonesia adalah agama Islam, yang dijadikan salah satu alat untuk memenangkan memenangkan politik.

\section{Hate Speech dan Media Sosial}

Dalam politik, banyak strategi yang digunakan dalam proses pemenangan kontestasi (Firdaus, 2013), termauk hate speech. Ada beberapa definisi "hate speech (Ujaran Kebencian)". Eric Heinze (2016) dalam bukunya yang berjudul Hate Speech and Democratic Citizenship menyebutkan bahwa pesatnya ujaran kebencian dalam kontestasi politik di berbagai negara dalam satu dekade belakangan ini dilatari oleh setidaknya ada dua faktor. Pertama, masih banyaknya sikap prasangka buruk satu kelompok masyarakat terhadap kelompoklainnya. Prasangka buruk berawal dari kebiasaan masyarakat yang gemar mengidentifikasi suatu kelompok dengan suatu pelabelan (stereotype) terentu. Prasangka berkaitan dengan stereotype. Ketika seseorang memiliki prasangka terhadap sesuatu atau seseorang, maka akan timbul suatu anggapan dan persepsi di mana kelompok tersebut dikategorikan, apakah baik, ataupun buruk (Hernawan, 2017).

Meski begitu, stereotype bersifat tidak akurat, karena stereotype berdampak pada pengabaian hal-hal yang berada dalam diri seorang individu dan belum tentu ada pada orang lain (Murdianto, 2018). Stereotype dapat memberi dampak positif dan negatif. Brislin menyebutkan bahwa stereotype dianggap sebagai pedang bermata dua, di satu sisi bersifat sebagai aspek penting dan efisien dalam berpikir, dan di sisi lain menghasilkan pengelompokan-pengelompokan yang membedakan satu kelompok dengan kelompok lain (Maryam, 2017). Stereotype yang berkelanjutan dapat menghasilkan diskriminasi dan hate speech di media-media sosial. Di Twitter, contoh satu kasus stereotype yang sudah terjadi adalah ketika Joel Ward, salah satu pemain Hockey ras Afrika-Amerika di Washington, AS, menjadi salah satu pemain yang paling sering mencetak gol dalam pertandingan Hockey melawan tim Boston pada April 2012. Pelabelan negatif dalam kelompok tertentu seringkali menjadi mula lahirnya ujaran kebencian kepada kelompok tersebut. Prasangkaburuk telah menjadi semacam endemik di tengah masyarakat inilah yangkerap dimainkan oleh elit politik untuk menuang perhatian publik.

Kedua, adalah adanya sikap inferior lantaran merasa tersisih atau terpinggirkan dari perebutan ruang sosial.Inferior inilah yang tidak jarang mengerucut pada sikap merasa terancam atas eksistensi kelompok yang mendominasi ruang sosial. Dalam konteksini, ujaran kebencian lebih merupakan bentuk dari startegi untuk mendelegitimasi kelompok yang tengah dominan di ruang sosial. Kondisi yang demikian kerap terjadi dalam konteks perebutan kekuasaan politik. Pihak-pihak yang kalah dalam pertarungan politik kerap 
menjadikan ujaran kebencian sebagai senjata untuk melemahkan domisi rezim yang berkuasa. Biasanya, praktik ujaran kebencian itu di klaim sebagai bentuk kritsisme dan kebebasan perpendat yang dijamin dalam sistem demokrasi.

Teori ritual view menyebutkan bahwa komunikasi adalah sebuah konstruksi realitas simbolik yangmerepresentasikan, mengadaptasi, dan menyebarkan suatu keyakinan masyarakat. Ritual view bertujuan untuk mempertahankan keberadaan kelompoknya untuk waktu yang lama. Dalam ritual view of communication, Carey melihat proses komunikasi yang terjadi adalah mendatangi massa, yaitu tindakan yang dilakukan bukan untuk menambah informasi, namun untuk mengekspresikan kepada orang-orang bahwa dia adalah bagian dari massa tersebut (Hardiman, 2017). Hate speech di media sosial merupakan salah satu peristiwa yang terjadi akibat dari ritual view di sosial media. Di dalam ritual view, individu yang merasa bagian dari kelompok tertentu, akan berusaha untuk menunjukkan dan memperkuat kelompoknya dengan cara bergabung di grup Facebook atau mengikuti fanpage, mengikuti dengan cara menfollow akun Instagram yang satu pandangan dengan individu tersebut, selain itu individu juga cenderung menyebarkan atau men-like berita yang menaikkan derajat kelompoknya. Selain berinteraksi dengan sesama anggota, individu juga mengekspresikan kelompoknya dengan ikut berkomentar terhadap berita atau status yang cenderung menurunkan derajat kelompok. Bentuk komentar tersebut dapat berupa pembelaan diri, atau berbentuk kata-kata kasar terhadap anggota kelompok yang berbeda pandangan dengan dia, sehingga menimbulkan konflik yang berujung dengan kata-kata kebencian atau hate speech.

\section{Metode Penelitian}

Studi ini menggunakan pendekatan kualitatif dengan metode content analysis. Walizer, sebagaimana dkutip Tiurina (2018) menyatakan bahwa metode ini merupakan penelitian yang bersifat membahas isi suatu informasi tertulis yang ada di dalam media. Dalam penelitian ini, akan diambil metode analisis teks dan dokumen untuk melakukan analisis terhadap konten-kontenterhadap data berupa kata-kata dan gambar, dimana data tersebut akan didapat melalui facebook dan Instagram. Analisis ini nantinya akan menggunakan analisis deskriptif dalam menganalisis data yang ada. Jenis dan sumber data yang diambil adalah Instagram dan Facebook, yang sekunder berasal dari buku-buku, serta jurnaljurnal. Tujuan dari analisis isi adalah untuk mengkategorisasikan data dan mengidentifikasi pola dari suatu chat atau teks. Media sosial merupakan salah satu media online dengan para penggunanya bisa dengan mudah berpartisipasi, berbagi dan menciptakan blog, jejaring media sosial. Jejaring sosial terbesar antara lain penggunaannya adalah Facebook, intagram. Data dari facebook adalah dari beberapa grup Facebook, contoh Pertama, Grup NKRI Harga Mati. Kedua, Grup Rakyat Bersatu Mendukung Jokowi RI 2014. Ketiga, Masyarakat Anti Fitnah. Keempat Jokowi Presiden RI. Kelima Prabowo for NKRI. Keenam Dukungan 200 Juta Ahok untuk Rakyat Indonesia Jokowi-Ahok. Maka dari itulah mengapa dipilih tempat tersebut sebagai tempat penelitian. Sedangkan data di Instagram masuk ke salah satu admin Instagram yaitu, pertama Jokowi 2019, kedua info sekitar Jokowi disana juga akan mudah untuk mendapatkan hasil penelitian yang relevan dan mudah dan pada zaman modern ini hand phone adalah alat yang digunakan supaya berkomunikasi dan mendapatkan informasi.

\section{Hasil}

Ada dua tipe ujaran kebencian berbasis agama yang menjadi sorotan dalam studi ini yaitu Facebook dan Instagram. Pada Facebook ada tiga momen dalam kontestasi politik yaitu pada tahun 2014, 2017 dan 2019 memiliki tipe yang berbeda serta ada kesamaannya. Ada tiga momen ujaran kebencian berbasis agama di Facebook yaitu pada moment politik 2014, 2017, 2019. Pada momen 2014 ujaran kebencian lebih mengarah kepada Joko Widodo. Merujuk sebuah proses yang terjadi sebelumya di tahun 2014 , strategi yang digunakan kampanye dan materi yang disampaikan kedua paslon memiliki karakter yang hampir sama. Namun demikian, narasi kampanye negatif (negative compaingn) dan bahkan kampanye hitam (Black Compaign) yang dipakai untuk kampanye pada tahun 2014 adalah rujukan yang telah disepakati terutama dalam perluasan isu berita bohong dan ujaran kebencian yang menyulut terjadinya konflik di antara pendukung paslon (Apriliana, 2019). Setiap paslon mencari titik lemah yang berpotensi terhadap berkurangnya dukungan pemilihan dari paslon lawan dan dapat beralih dukungan kepada dirinya. Oleh karena itu isu identitas yang menjadi pusat perhatian para paslon adalah penting dimobalisasi dalam 
meraih dukungan (Fernandes, 2019; Herdiansah, 2017). Pada pemilu 2014, isu terkait status Prabowo sebagai jendral angkatan darat, dan isu dalam kepemilikan usaha asing, sedangkan Joko Widodo dan partainya dengan China, ataupun menyangkut kadar keislaman seseorang dalam ibadahnya.

Kategori hoax berisi suatu informasi berita yang bohong yang dikaitkan dengan status dan komentar sehingga dalam kategori ini umumnya berisi ujaran yang seakan-akan berita yang disampaikan benar sesuai dengan kenyataan dan fakta nyata, namun kebenarannya adalah berita bohong, sehingga masyarakat tidak bisa membedakan mana berita fakta atau hoax. Status pada gambar 1 misalnya, mengatakan bahwa "ada pemimpin yang belum jelas latar belakang keluarganya". Padahal, faktanya latar belakang Joko Widodo adalah keturunan suku Jawa yang lahir di Surakarta 21 Juni 1961.

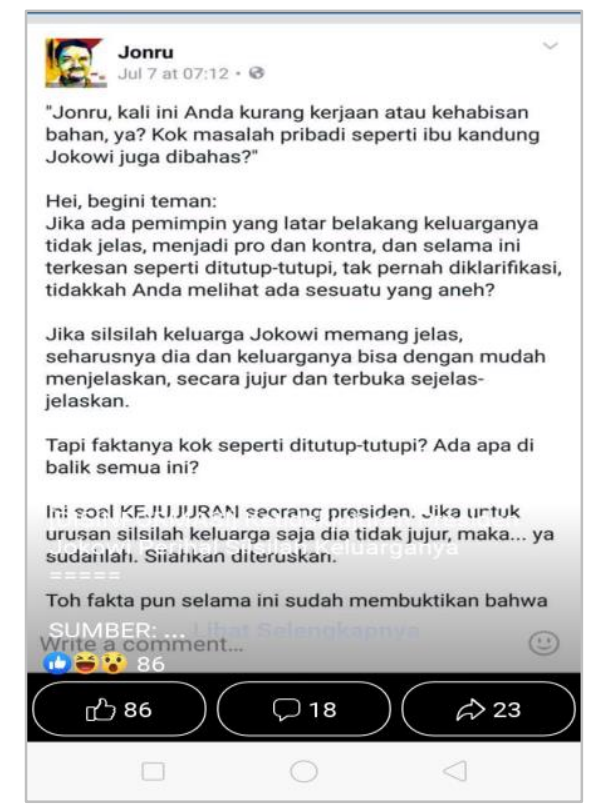

Gambar 1. Contoh Status Hoax

\subsection{Tipe Ujaran Kebencian di Facebook pada Kontestasi Politik 2017}

Berita mengenai penistaan agama dilakukan Ahok menjadi perbincangan hangat. Debora (2016) menyatakan bahwa Ahok pada saat itu ditetapkan sebagai tersangka oleh kepolisian yang terkait dengan dugaan penistaan agama yang menyangkut ucapannya terkait dengan surat yang tertera di dalam kitab suci Al-Qur'an yaitu surat Al-Maidah 51 pada bulan September lalu di Pulau Seribu.

Menurut Nurdin (2017) pernyataan Ahok berhubungan dengan konteks surat AlMaidah ayat 51, kemudian menjadi perbincangan masyarakat dan menimbulkan demonstrasi terbesar pada tanggal 4 november 2016. Melalui media sosial semakin memicu besarnya tekanan masa yang kontra dengan Ahok. Ucapan kasar atau ungkapan kebencian banyak terlontar di akun media sosial misalnya ungkapan "tangan raja Salman kena najis dari tangan Ahok".

Makian merupakan kategori yang berisi postingan terkait dengan hate speech terhadap Ahok yang memiliki konten kasar atau tidak pantas untuk diucapkan di depan publik. Dalam kategori ini, menemukan banyak status atau komentar yang menggunakan katakata kasar dengan bahasa Indonesia terhadap target, baik terhadap Ahok, kelompok tertentu, atau penjabat tertentu. Misalnya, salah satu komentar ada yang menghina dengan mengatakan bahwa Ahok adalah bajingan. Konten yang tidak pantas di ucapkan pada salah satu komentar. Dalam kategori ini juga termasuk sikap prasangka yang buruk kepada suatu kelompok tertentu.

Konten di atas sama juga dengan kategori makian misalnya, status agama ada yang menghina FPI dengan sebutan "bangsat dan 'penebar fitnah', ada pula yang menulis 'kuntil babi, anjing yang di tunjukan kepada Ahok.Selain itu banyak ditemukan menggunakan kata-kata kasar dengan bahasa inggris ada pula yang menulis 'What Fucking septictank mouth' terhadap Ahmad Dhani yang menentang Ahok, serta salah satu organisasi FPI juga di sangkutkan dalam pemilihan Ahok. Selain itu banyak ditemukan menggunakan kata- 
kata kasar dengan bahasa Inggris, ada pula yang menulis 'What Fucking septictank mouth' terhadap Ahmad Dhani yang menentang Ahok, serta salah satu organisasi FPI juga di sangkutkan dalam pemilihan Ahok tersebut, berikut contoh dari ujaran kebencian.

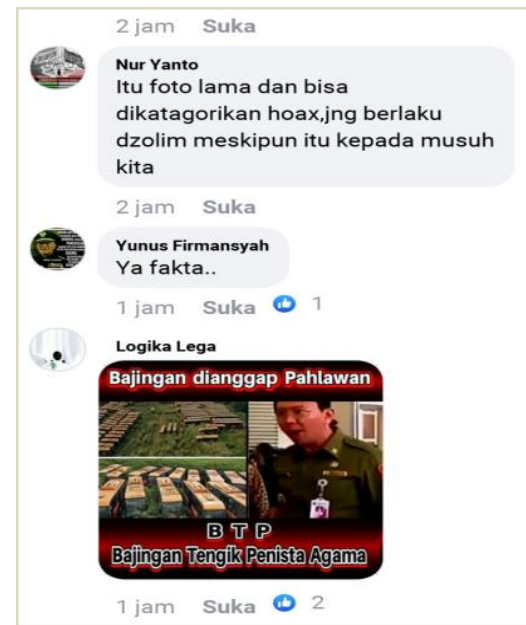

Gambar 2. Contoh Penghinaan Terhadap Ahok Dalam Komentar Facebook

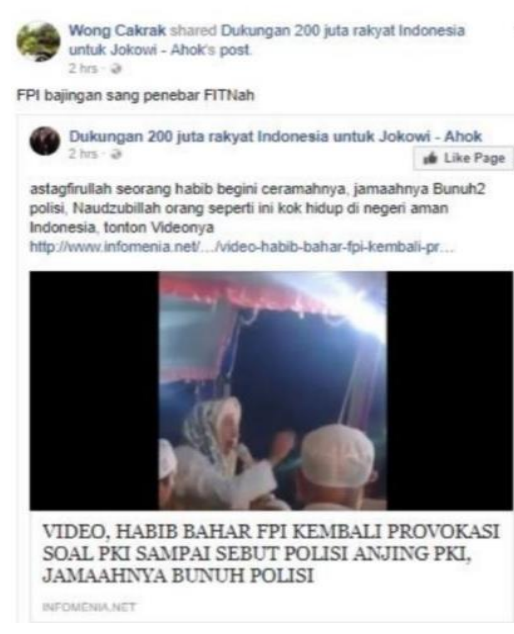

Gambar 3. Contoh komentar miring terhadap FPI di laman Facebook

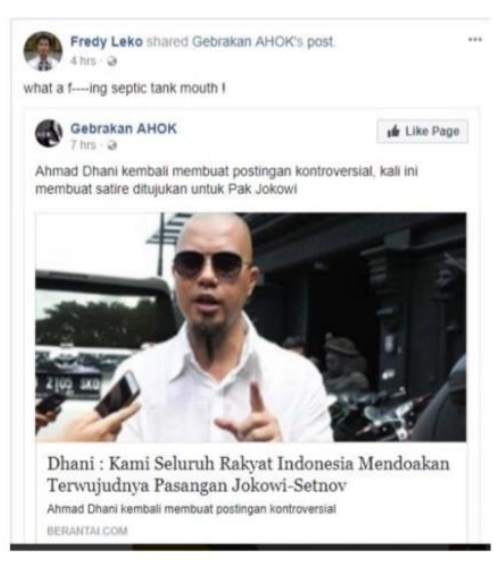

Gambar 4. Contoh Status Kategori 'Makian'

Kategori 'ancaman' berisi postingan yang memiliki konten mengancam kelompok atau individu tertentu. Berdasarkan kategori ini, ditemukan bahwa 'ancaman' yang ditulis berkaitan dengan hate speech terhadap Ahok banyak yang merujuk pada kelompok tertentu. Sebagai contoh yaitu status yang melampirkan gambar yang berisi informasi bahwa seorang pendukung Ahok yang melecehkan agama dan serta ikut takbir hingga tewas dalam sebuah kecelakaan, dan pengguna tersebut menulis 'siapa berikutnya? Ahoker cebonger siap-siap ya Allah bayar kontan penghina kalian!', salah satu contoh yang termasuk kategori ancaman.

Kemudian, kategori ancaman menggunakan lambang Garuda pancasila. Sebagai salah satu konten status yang membahas tentang "jika pemerintahan Joko Widodo diam atas desakan aksi 505 yang memaksakan kehendak atas pengadilan Ahok, buat saya Indonesia sudah bubar. Aksi bunga-bungaan tidak diperlukan lagi. Mari bersikap lantang bubarkan FPI anansir radikalisme atau Indonesia timur merdeka". Ancaman pemberontakan seperti "kalau Ahok tidak dipenjara, Islam dan bangkit, dan nada pula yang mengancam dengan berujar '.......Bubarkan FPI anasir radikalisme, atau Indonesia Timur meredeka!' melalui statusnya.
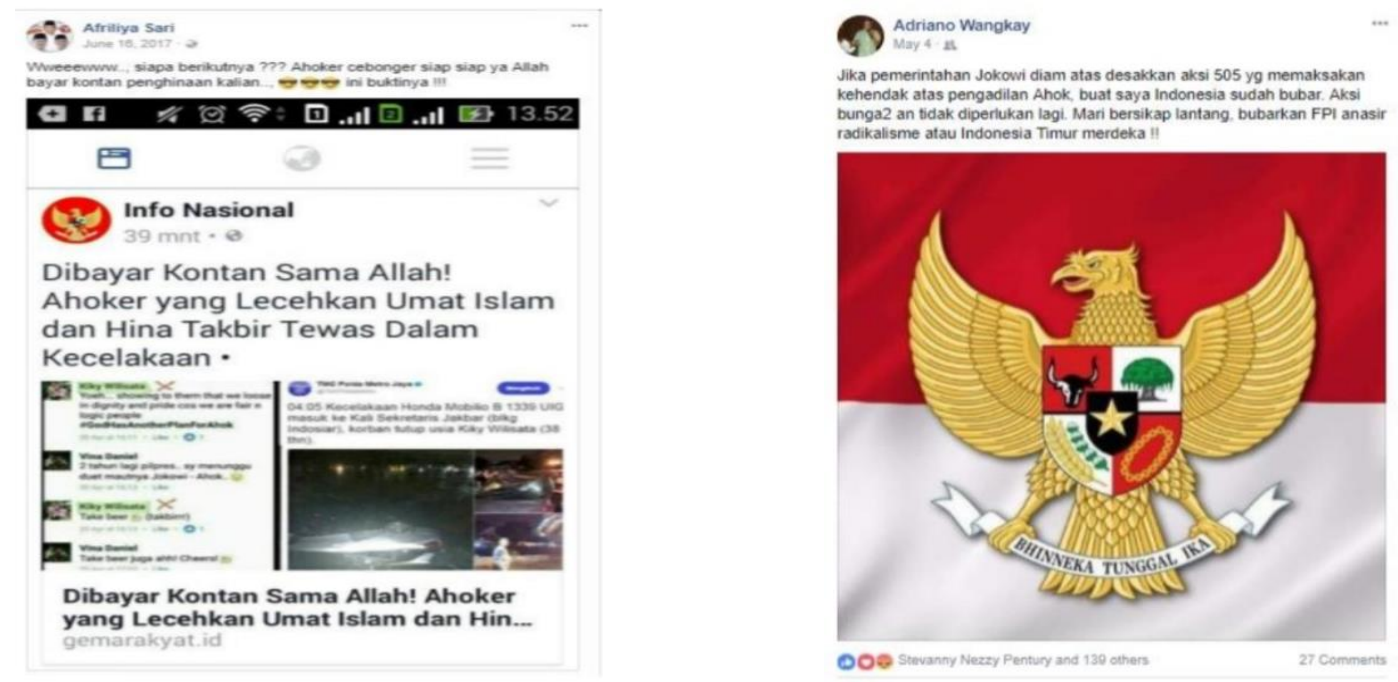

Gambar 5. Contoh Status Kategori 'Ancaman' 
Kategori 'kritik negatif' berisi status atau komentar yang memiliki konten menyalahkan suatu pihak. Komentar atau status termasuk kategori ini umumnya berisi ujaran kebencian bahwa mereka yang mendukung Ahok adalah kafir, atau menyebut orang yang menolak dan membenci Ahok adalah penyebab dari rusaknya NKRI. Ketegori ini juga termasuk pada status yang berkata bahwa mereka memilih atau melawan Ahok akan menyesal. Di dalam kategori ini, ditemukan bahwa sebagian besar postingan masuk dalam kategori 'kritik negatif'.

Konten kritik negatif sama juga dengan halnya status yang menggunakan gambar banjir yang mengatakan "setiap bulan kebanjiran, warga Bukit Duri menyesal gugat Ahok dan mau dipindahkan. Hidayah memang datang belakangan. Kritik negatif ini biasanya di gunakan untuk menyalahkan suatu pihak tertentu.

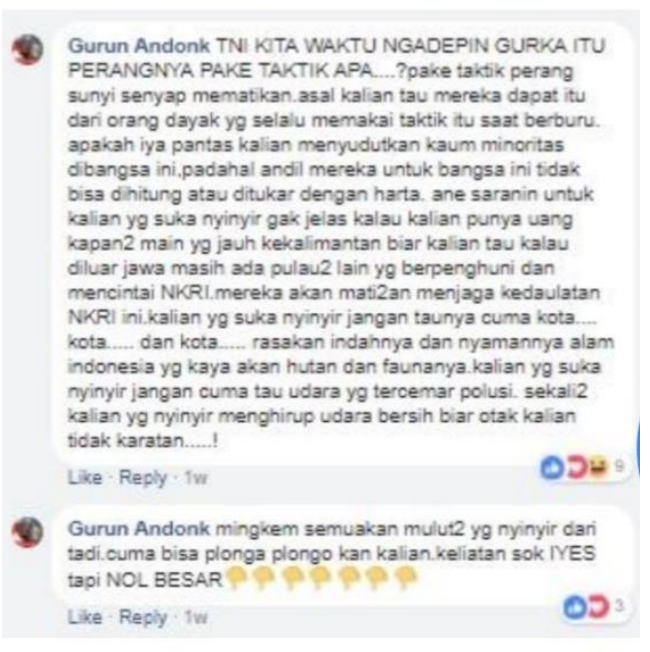

Gambar 6. Contoh Komentar Kategori 'Kritik Negatif'

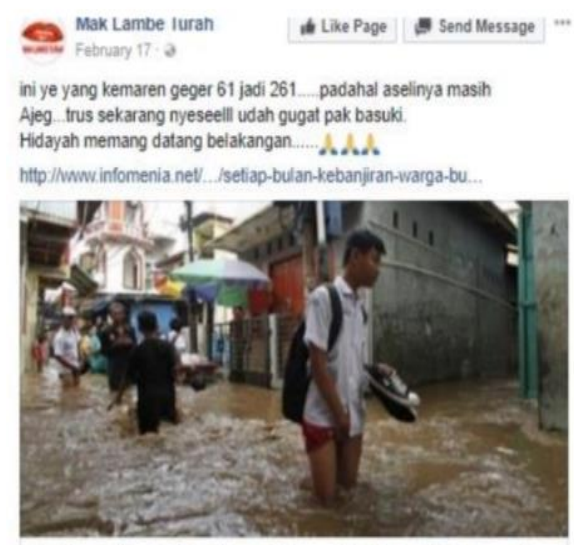

Setiap Bulan Kebanjiran, Warga Bukit Duri Menyesal Gugat Ahok Dan Mau dipindah Asal........

Permukiman warga Bukt Dur di RT O1/12 kembal terendam banic, Kamis 16

37 Reractions 450 Comments $13.3 \mathrm{~K}$ Shanes

$\varphi=$

Gambar 7. Contoh Status Kategori 'Kritik Negatif”

Sedangkan kategori 'lainnya' dikhususkan pada status atau komentar yang tidak mengandung unsur hate speech, meskipun dalam postingannya, mereka menunjukan bahwa mereka berada di pihak tertentu. Dalam kategori ini, penulis menemukan bahwa postingan yang termasuk kategori 'lainnya' semuanya serupa komentar dari status tertentu. Setara dengan contoh kategori lainnya di atas ada salah satu komentar yang berisikan dia memuji Ahok yang termasuk dalam kategori 'lainnya' berisi pujian terhadap Ahok, misalnya memuji bahwa Ahok adalah anak Tuhan yang baik. Doa terhadap Ahok ataupun pihak lain juga termasuk dalam kategori ini.

Iffan Setiawan Assalammualaikum, p'Anis,? Saya bukan asli Jakarta,tp sy dukung Bpk, saya doakn smg Allahswt memilh bapak s'bagai pemimpin d Jakarta,... sy dari Labuan Pandeglang Banten.

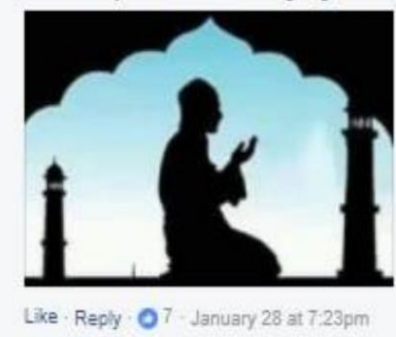

Gambar 8. Contoh Status Kategori 'Lainnya'

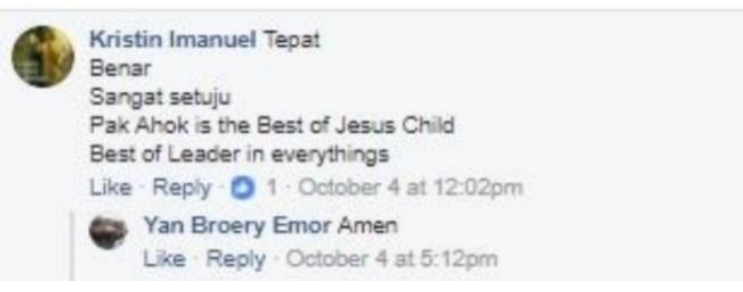

Gambar 9. Contoh Komentar Kategori 'Lainnya'

\subsection{Tipe Ujaran Kebencian di Facebook pada Kontestasi Politik 2019}

Hate speech merupakan poin utama dalam studi ini. Sebelum pemilihan 17 april, pemilihan presiden sering digambarkan sebagai pertarungan ideologi antara pendukung Joko Widodo dan pendukung Prabowo, pada pemilihan tahun (pilpres 2019) ini memasuki 
babak baru yaitu pertarungan ideologis antara pendukung komunisme dan pendukung khilafah. Kubu Joko Widodo dikesankan sebagai mereka yang mendukukung kembalinya partai komunis Indonesia (PKI), yang sudah dibubarkan pada tahun 1966 oleh Jenderal Soerharto. Sementara itu, kubu Prabowo dianggap sebagai tempat berkumpulnya kelompok HitburTahrir Indonesia (HTI) yang sudah dibubarkan pada tahun 2017 oleh presiden Joko Widodo, dengan alasan HTI hendak mengubah ideologi negara Kesatuan Republik Indonesia NKRI menjadi negarakhilafah (Nadisyah: 2018). Jendral purnawirawan memberikan keterangan pres pada tanggal 29 maret 2019 pilpres kali ini adalah pertarungan antara pancasila vs khilafah. Kubu 02 memang sudah sejak lama memainkan isu PKI ini untuk menyerang Joko Widodo. Bermula dari pilpres 2014, lima tahun sebelumya, ketika tabloid obor rakyat menuduh mempertanyakan sisilah keluarga Joko Widodo yang selama ini beredar. Ibu Joko Widodo juga diragukan sebagai ibu asli. Sosok Joko Widodo dianggap memanipulasi data pendidikannya, para buzzer 02 terus menggoreng isu ini di tahun 2019 dan dikesankan bahwa Joko Widodo, selama 5 tahun terakhir telah berusaha menutupi sosok dia dan keluarga yang sebenarnya. Ditambah lagi dengan tuduhan bahwa sejumlah anak tokoh PKI sekarang bergabung di Partai Demokrasi Indonesia Perjuangan (PDIP) yang menjadi basis utama kekuatan politik Joko Widodo.

Untuk mempermudah analis yang terkait hate speech ujaran kebencian terhadap presiden Joko Widodo, Joko Widodo digambarkan sebagai seorang yang komunis dan sorang Kristen Cina yang berencana untuk menjual Indonesia ke Cina. Klaim ini dibuat bahwa, jika terpilih kembali, ia berencana untuk menghilangkan pengajaran agama di sekolah umum, mendukung pernikahan sesama jenis, melarang terdengarnya suara azan (panggilan untuk shalat), dan melarang wanita untuk mengenakan jilbab, klaim yang tidak memiliki fakta. Komentar di media sosial banyak tersebar dengan menggambarkan Joko Widodo sebagai anjing dan pendukungnya sebagai kotoran anjing, babi, atau sebagai orang yang memakan daging babi yang semua itu dilarang dalam Islam, dan sebagai seorang muslim Syiah seorang Zionis, Cina atau agen Amerika. Dan yang terakhir contoh ujaran kebencian bernuansa agama pada moment politik 2019 dalam pemilihan presiden dan wakil presiden 2019, contoh tipe ujaran kebencian yang di pakai pada tahun 2019 ini tidak jauh beda dengan tipe ujaran kebencian yang di pakai pada pemilihan tahun sebelumya 2014 dan 2017 status dan komentar tersebut ke dalam 3 tipe yaitu:

Contoh status dan gambar ujaran yang berkaitan dengan kontestasi politik pada tahun 2019. Dari kategori hate speech di Facebook yang berisi sindiran atau sarkasme, seperti contoh komentar yang mengatakan 'Joko Widodo memang hebat, coba lihat penista agama, menghina nabi bebas berkeliaran, tetapi penghina orang biasa langsung di tangkap. Sejak pemerintahan Joko Widodo orang biasa lebih tinggi derajatnya dari pada Nabi, hebatkan....'

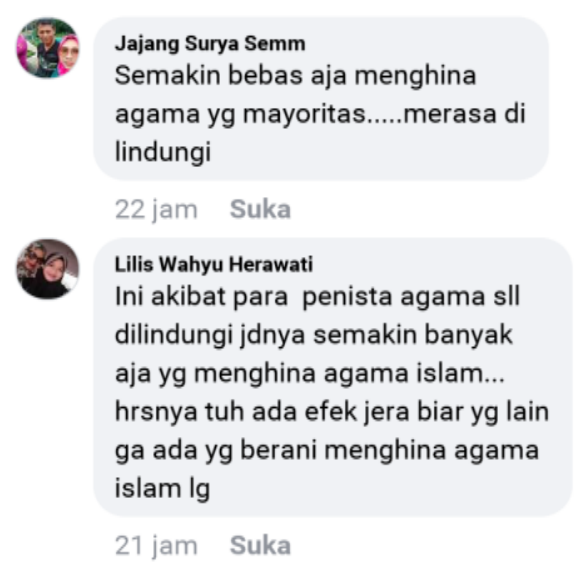

Gambar 10. Contoh Komentar Kategori 'Sindiran/Sarkasme'

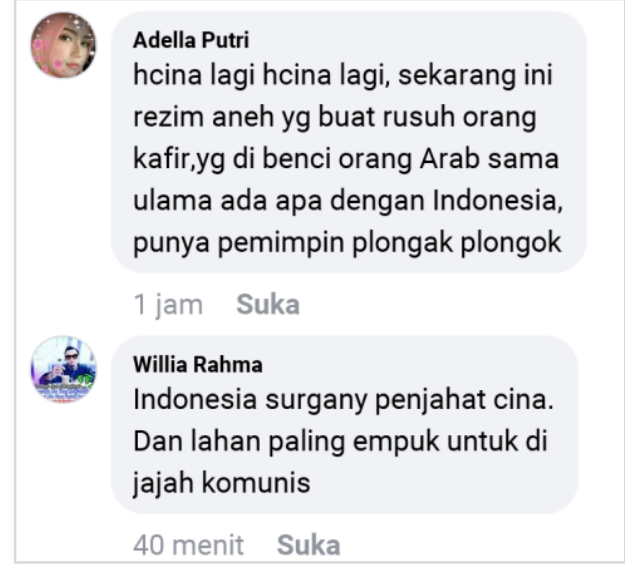

Gambar 11. Contoh Komentar 'Kritik Negatif

Kategori kritik negatif berisi status dan komentar yang memiliki seolah-olah menyalahkan suatu pihak. Dalam hal ini, komentar atau status yang termasuk dalam ketegori ini pada umumnya berisi ujaran bahwa mereka yang mendukung presiden Joko Widodo adalah seorang komunis Cina, atau yang memilih Joko Widodo nanti akan ada klaim ini dibuat bahwa, jika terpilih kembali, ia berencana untuk menghilangkan 
pengajaran agama di sekolah umum, mendukung pernikahan sesama jenis, melarang terdengarnya suara azan (panggilan untuk shalat), dan melarang wanita untuk mengenakan jilbab, klaim yang tidak memiliki fakta. kategori ini termasuk pada status bahwa yang mereka atau memilih atau melawan presiden akan menyesal. Di dalam kategori ini, postingan yang termasuk dalam kategori kritik negatif.

Konten di atas sama halnya dengan salah satu komentar kritik negatif yang mengatakan bahwa "kalian bilang semoga Indonesia bisa bantu Turki. Apalah yang bisa di harapkan dari Indonesia ini, punya teknologi presiden yang macam itu pula, palingan dia bilang itu bukan urusan saya" dalam kategori kritik negatif di sama sekan-akan negara yang mayoritas muslim yang bisa di atur dengan uang oleh orang kafir.

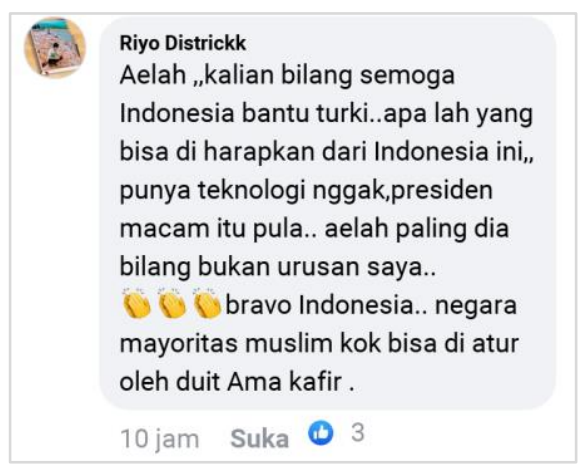

Gambar 12. Contoh Komentar 'Kritik Negatif'

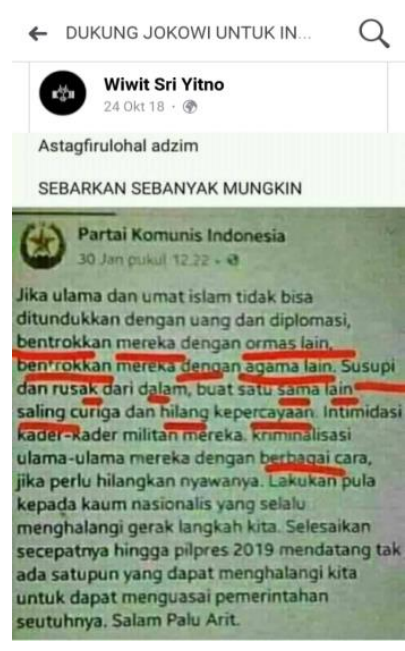

Gambar 13. Contoh Status Kritik Negatif'

Salah satu status yang digunakan dalam tipe status kritik negatif yang berisi jika umat Islam tidak bisa ditundukkan dengan uang dan diplomasi, maka berontak mereka dengan ormas lain, diberontak mereka dengan agama lain. Selesaikan secepatnya hingga pilpres 2019 mendatang hingga tak satupun yang dapat menghalangi kita untuk menguasai pemerintahan seutuhnya.

Kategori ancaman yang berisi postingan yang memiliki konten yang mengancam suatu kelompok atau individu tertentu. Berdasarkan kategori ini, saya menemukan bahwa kategori atau tipe dari ancaman yang ditulis berkaitan dengan hate speech terhadap Joko Widodo banyak yang merujuk kepada kelompok tertentu. Sebagai salah satu contoh, ada sebuah komentar yang melampirkan kata-kata yang berisi bahwa kalau tidak mau di kritik semua agama harus adil, jangan tembang pilih kalau tak mau di kririk. Jangan jadi pemimpin kalau tak mampu silahkan mundur.

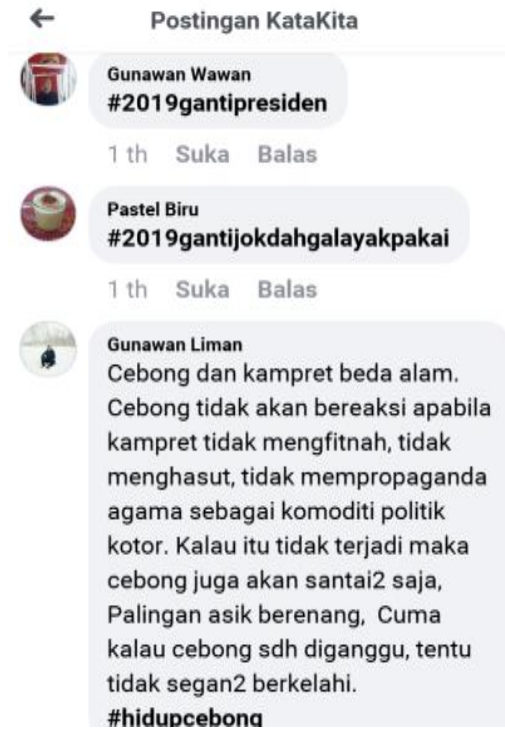

Gambar 14. Contoh Komentar Kategori Ancaman

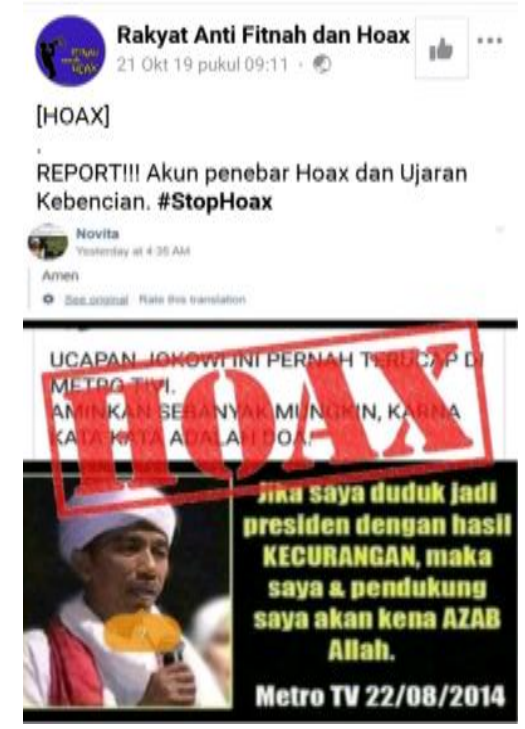

Gambar 15. Contoh Status Kategori 'Hoax' 
Dan ada juga dalam contoh di atas menggambarkan bahwa pendapat para netizen atau komentar yang berisi ujaran kebencian, berisi bahwa pada tahun 2019ganti presiden. Bahwasanya juga dijelaskan di salah satu komentar para cebong adalah para (pendukung Joko Widodo) dan para kampret yang di kenal juga dengan (pendukung Prabowo), maksud dari komentar salah satu di atas adalah bahwasanya para pendukung Joko Widodo tidak akan bereaksi apabila para pendukung Prabowo tidak menfitnah, menghasut, serta tidak mempropagandakan agama sebagai komoditi politik yang kotor.

Kategori hoax atau berita palsu atau berita bohong atau hoax adalah informasi yang sesungguhnya tidak benar, tetapi dibuat seolah-olah benar adanya. Banyak yang memakai kategori ini untuk menyebarkan ujaran kebencian yang berbasis agama sehingga nantinya memenangkan suatu pihak tertentu demi meraih kemenangan politik yang kotor dengan cara memberikan berita hoax tersebut, seperti contoh di bawah ini apabila saya duduk jadi presiden dengan hasil kecurangan maka saya dan pendukung saya akan kena azab Allah. Dari data di atas dapat di kategorikan tipe -tipe dari ujaran kebencian bernuasa agama, maka dapat ditemukan dari 756 data dan memasukannya kedalam tabel untuk melakukan tabulasi dan presentasi sebagai berikut ini:

Tabel 1. Konten Hate Speech pada Status dan Komentar di Facebook

\begin{tabular}{|c|c|c|c|c|c|}
\hline \multirow{2}{*}{ No } & \multirow{2}{*}{ Jenis Hate speech } & \multicolumn{2}{|c|}{ Jenis } & \multirow{2}{*}{ Jumlah } & \multirow{2}{*}{ Persentase } \\
\hline & & Status & Komentar & & \\
\hline 1 & Sindiran /makian & 25 & 300 & 325 & $43 \%$ \\
\hline 2 & Makian & 9 & 66 & 75 & $10 \%$ \\
\hline 3 & Ancaman & 2 & 5 & 7 & $1 \%$ \\
\hline 4 & Kritik Negatif & 5 & 92 & 97 & $12 \%$ \\
\hline 5 & Distorsi & 3 & 70 & 73 & $10 \%$ \\
\hline 6 & Hoax / kebohongan & 2 & 135 & 137 & $18 \%$ \\
\hline \multirow[t]{2}{*}{7} & Lainnya & 1 & 50 & 51 & $7 \%$ \\
\hline & TOTAL & 47 & 718 & 765 & $100 \%$ \\
\hline
\end{tabular}

Sumber: Diolah dari Berbagai Sumber

Berdasarkan data di atas dapat diketahui dari 765 data, mayoritas masyarakat menggunakan sarkasme atau sindiran dalam menyebarkan hate speech atau ujaran kebencian yang terkait kontestasi politik 2014, 2017, 2019. Meskipun tiap pihak melakukan hate speech, namun sangat sedikit yang melakukan hate speech dengan kategori ancaman dengan kata-kata yang tidak pantas. Sebaliknya hate speech banyak dilakukan dengan yang bersifat sarkasme atau sindiran, dan tidak dengan kata-kata kasar atau bersifat mengancam.

Ujaran kebencian di Instagram adalah suatu jejaring sosial yang mempunyai tujuan untuk membantu penggunanya untuk membagikan atau mengunggah foto kepada pengguna Instagram yang lainnya (Rahman, 2014). Penulis memilih media sosial Instagram sebagai objek kajian karena media sosial tersebut yang paling populer saat ini. Terkait dengan kasus Ahok mengenai penistaan agama, banyak heaters yang melontarkan katakata kasar dikolom komentar foto saat Ahok mengunggah foto di akun Instagram. Sedangkan tipe ujaran kebencian yang dipakai di Instagram yang bernuansa agama di media sosial yang digambarkan secara umum, seperti penjelasan tabel di bawah ini, yang masing-masing tahun dari 2014, 2017, 2019 memiliki tipe seperti keterangan di bawah ini.

\subsection{Tipe Ujaran Kebencian di Instagram pada Kontestasi Politik (2017).}

Tipe ujaran kebencian kepada Ahok yang di Instagram pada tahun 2017 yang terdapat dalam akun media sosial Instagram Basukti menjelang pemilihan Cagub dan Cawagub DKI Jakarta terdapat beberapa tipe terkait dengan hate speech terhadap Ahok, pada pembagian tipe ini tidak jauh beda dengan tipe yang dipakai pada Instagram, pada tahun 2017 yang bernuansa agama maka peneliti membagi status dan komentar tersebut ke dalam 3 tipe hate speech berdasarkan konten dari postingan-postingan yang dianalisis, seperti terlihat dalam tabel 2.

Tabel 2. Tipe atau Kategori Hate Speech Agama Ahok di Instagram

\begin{tabular}{ll}
\hline No & Tipe Ujaran Kebencian yang Bernuansa Agama Ahok (2017) di Instagram \\
\hline 1 & Makian, menurut KBBI adalah kata keji yang diucapkan karena marah. \\
2 & Kritik negative. \\
3 & Dan Lainnya (berada di salah pihak) pujian. \\
Sumber: Diolah dari Berbagai Sumber
\end{tabular}


Makian merupakan kategori yang berisi potingan-postingan terkait dengan hate speech terhadap Ahok yang memilki konten-konten kasar atau tidak pantas diujarkan di depan publik. Dalam tipe ini penulis menemukan banyak status dan komentar menggunakan kata-kata kasar dengan bahasa Indonesia terhadap tagar Ahok, kelompok tertentu, atau penjabat tertentu. Penulis melihat bahwa terdapat banyak ujaran kebencian yang berisi makian misalnya berkat dengan kata-kata yang kasar yang berkaitan dengan seperti salah status yang berisi "Semoga anjing2 lainnya seperti pak BTP dan semoga berkurang bahkan segera hilang taik2 seperti para oknum penjabat tsb". BTP yang dimaksud ditujukan kepada Ahok.

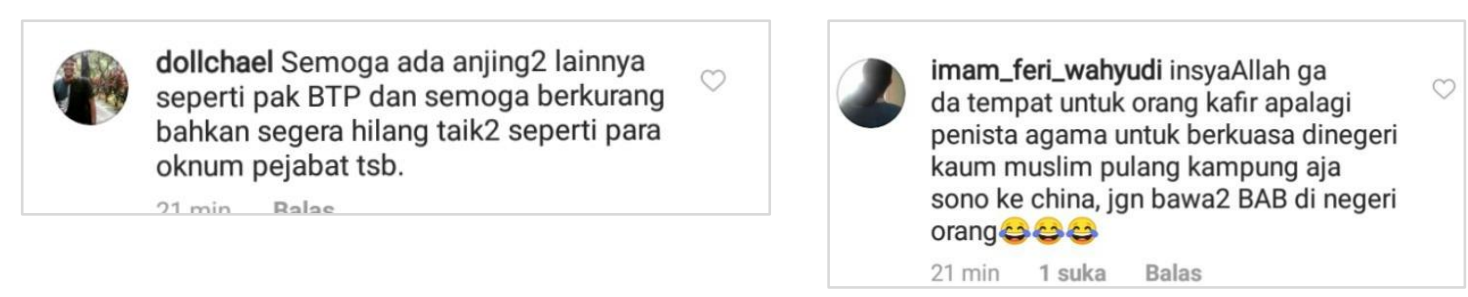

Gambar 16. Contoh Komentar Kategori Makian

Salah satu komentar juga menyangkut dengan agama dalam kategori makian yang dilontarkan untuk Basuki Tjahaja Purnama atau yang sering dikenal dengan Ahok adalah 'insyaa Allah tidak ada tempat untuk orang kafir apalagi penista agama yang berkuasa di Negeri kaum muslim pulang sono ke Cina, jangan bawa-bawa BAB di Negri orang.Dalam kategori makian ini mengatakan bahwa tak ada tempat bagi orang yang selain agama Islam dan bagi orang yang sudah menista agama, apalagi sampai berkuasa di Negeri kaum Muslim, secara halus mengusir untuk kembali ke negeri tempat asal Ahok yaitu Cina.Kategori kritik negatif berisi status atau komentar yang memiliki konten seolah-olah mengkritik pihak tertentu. Dalam hal ini, komentar yang termasuk kategori kritik negatif ini umumnya berisi ujaran kebencian bahwa seperti contoh di atas "Penista agama di puja2 wkwk sono aja ke laut jagain kerang". Dalam komentar tersebut dikatakan bahwa penista agama yang di puja-puja di buang saja ke laut sambil jagain kerang.

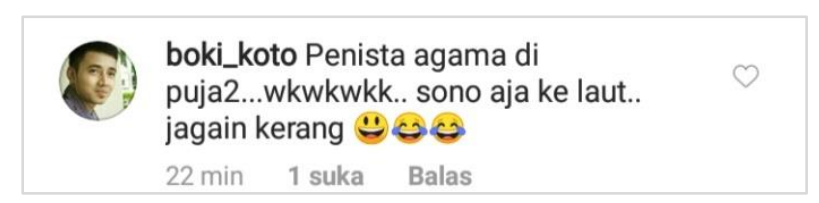
Gambar 17. Contoh Komentar 'Kritik Negatif'

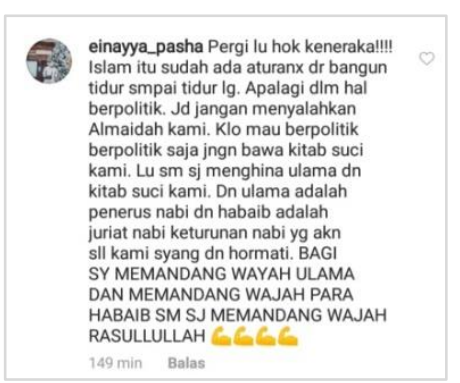

(2)

Sedangkan tipe lainnya dikhususkan pada status dan komentar yang tidak mengandung unsur hate speech, meskipun dalam postingannya, mereka menunjukan bahwa mereka berada di pihak tertentu. Dalam tipe ini, ditemukan komentar dari status tertentu maksud dan tujuan untuk membela Ahok. "Bener itu mas Ahok...mereka mau maling dan politik mengatas nama kan agama..itu bukan Islam tapi kedok untuk menutupi kebenaran..." dalam komentar di atas menunjukan bahwa pengomentar mendukung Ahok dan berada di salah satu pihak yaitu Ahok.
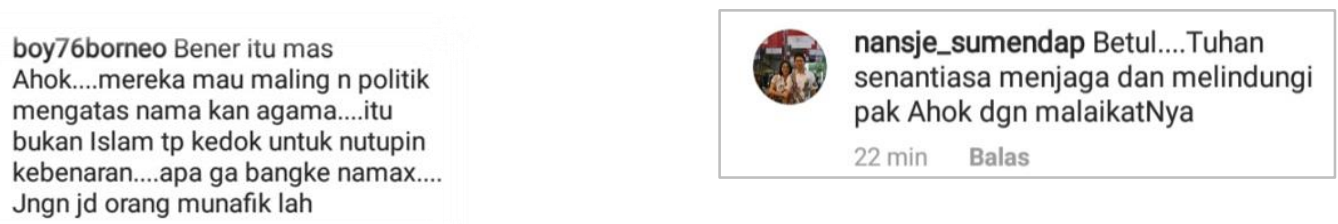

Gambar 18. Contoh Komentar Kategori Lainnya

Konten yang sama juga terjadi pada salah satu komentar dalam kategori lainnya, kategori lainnya menunjukkan mereka berada di salah satu pihak seperti salah satu 
komentar yang diambil dari Instagram Ahok "betul Tuhan senantiasa menjaga dan melindungi pak Ahok dengan malaikatnya", yang dalam hal komentar tersebut pengomentar berada di posisi Ahok, yang selalu mendokan Ahok.

\subsection{Tipe Ujaran Kebencian pada Kontestasi Politik di Instagram.}

Tipe ujaran yang di lontarkan kepada Joko Widodo di media sosial instagram terdiri dai sindiran, kritik negarif dan makian. Sindiran lebih merujuk kepada posting yang bersifat menyinggung suatu pihak dengan kata-kata yang halus. Dalam tipe tersebut, penulis melihat bahwa terdapat banyak hate speech di Instagram. Salah satu komentar dalam kategorisindiran/sarkasme yang di tujukan kepada Joko Widodo seperti "presiden Islam wakil kiyai...ko masalah umat Islam di bantai pada diam, giliran China di bantai teriak", maksudnya dalam komentar tersebut dikatakan bahwasanya Joko Widodo dan Wakil lebih membela orang china di bandingkan umat Islam.
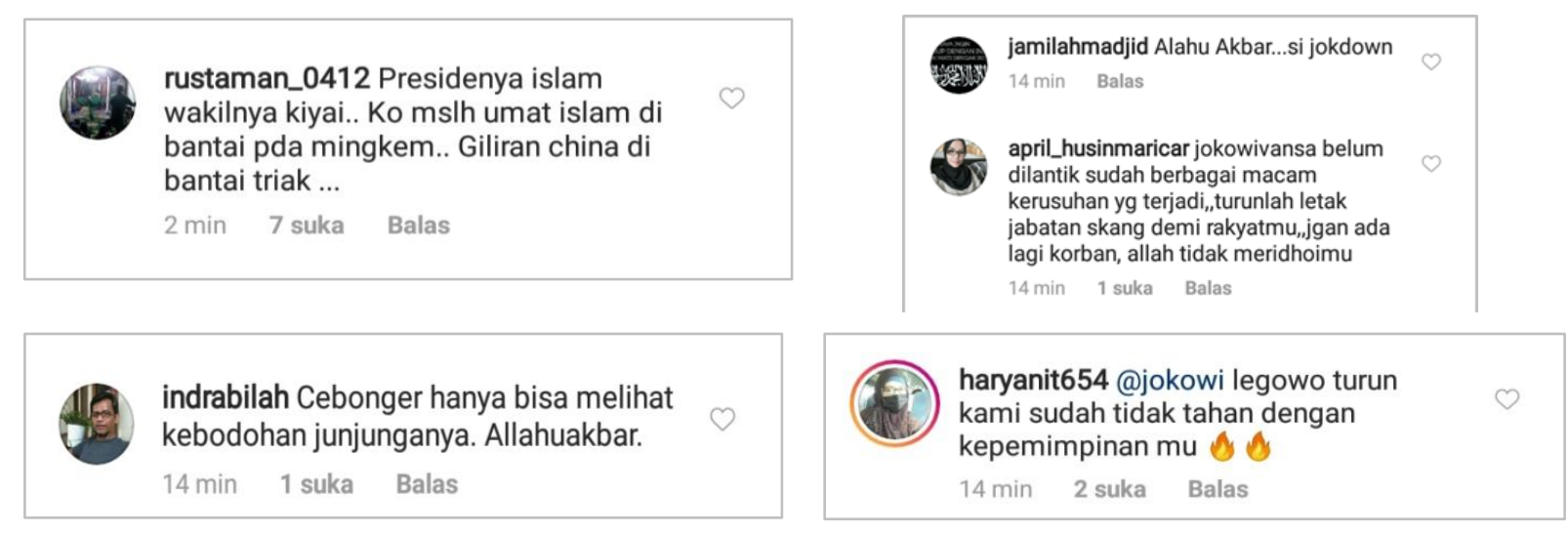

Gambar 19. Contoh Komentar Kategori Sindiran/Sarkasme

Sama halnya dengan konten sindiran atau sarkasme, seperti salah satu komentar yang berisi 'Jokowi belum di lantik sudah berbagai macam kerusuhan yang terjadi, turunlah letak jabatan sekarang demi rakyatmu, jangan ada lagi korban, Allah tidak meridhoimu. Sama dengan contoh yang ketiga yang termasuk dalam kategori sindiran/sarkasme yang mengatakan "Cebonger hanya bisa melihat kebodohan junjungan. Allahuakbar". Kata dari cebonger berasal dari kata cebong, biasanya cebong digambarkan dengan pendukung Joko Widodo, yang di maksud adalah para pendukung Joko Widodo hanya bisa melihat kebodohan dari atas junjungannya.

Konten di atas juga sama dengan konten yang sebelumnya yang termasuk dalam kategori sindiran atau sakasme terdapat data yang ditemukan di Instagram yang mengatakan "Jokowi turun kami sudah tidak tahan dengan kepemimpinanmu". Dia mengatakan sindiran untuk menyuruh Jokowi agar segera turun dari jabatannya". Makian yang merupakan kategori yang berisi postingan yang terkait terhadap Joko Widodo yang memiliki konten-konten yang kasar atau yang tidak pantas untuk diujarkan di depan publik. Dalam kategori ini, penulis menemukan bahwasanya ada status dan komentar yang menggunakan kata-kata yang kasar dengan bahasa Indonesia terhadap target, baik terhadap Joko Widodo, kelompok tertentu, atau pejabat tertentu. Misalnya, salah satu komentar yang menghina PKI dengan sebutan komunis, maling hak, yang di tunjukan kepada para pemimpin Indonesia.

picture.indonesia18 NKRI sudah di
rampas oleh gerombolan pki komunis
dan para maling Hak rakyat indonesia,
skrng indonesia di pimpin para koruptor
13 min 1 suka Balas

Gambar 20. Contoh Komentar Ketegori Makian

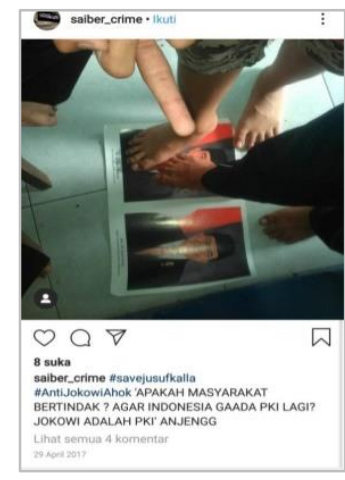

Gambar 21. Contoh Status Kategori Makian 
Dalam kategori makian seperti contoh yang di atas ada pula contoh yang lain seperti pada salah status yang menggunakan kata-kata yang kasa yang menulis "Joko Widodo adalah PKI anjeng". Kata anjing adalah kata kasar yang digunakan untuk menghina Joko Widodo melalui kata-kata tersebut.

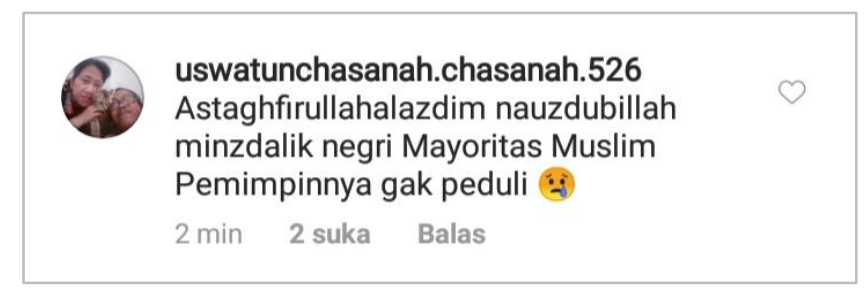

Gambar 22. Contoh Komentar Ketegori 'Kritik Negatif'

Dalam kritik negatif yang ditunjukan untuk membela salah satu pihak, data yang di temukan dalam salah satu komentar dari kategori 'kritik negatif' adalah "Astagfirullahalazdhim nauzdhubillahminzdalik Negri mayoritas muslim pemimpinnya gak peduli". Dari kata-kata tersebut mengatakan bahwa pemimpin tidak peduli terhadap rakyat yang mayoritas Muslim. Dari data di atas maka penulis memilah data ternyata dapat di kategorikan tipe-tipe dari ujaran kebencian bernuasa agama, maka penulis memilah dari 72 data dan memasukannya ke dalam tabel untuk melakukan tabulasi dan presentasi sebagai berikut ini:

Tabel 3. Konten Hate Speech pada Status dan Komentar di Instagram

\begin{tabular}{cccccc}
\hline \multirow{2}{*}{ No } & \multirow{2}{*}{ Jenis Hate speech } & \multicolumn{2}{c}{ Jenis } & \multirow{2}{*}{ Jumlah } & \multirow{2}{*}{ Persentase } \\
\cline { 3 - 4 } & & Status & Komentar & & \\
\hline 1 & Sindiran/sarkasme & 2 & 25 & 27 & $38 \%$ \\
2 & Makian & 1 & 20 & 21 & $29 \%$ \\
3 & Kritik Negatif & 1 & 12 & 13 & $18 \%$ \\
4 & Lainnya & 1 & 10 & 11 & $15 \%$ \\
\hline \multicolumn{2}{r}{ TOTAL } & 5 & 67 & 72 & $100 \%$ \\
\hline
\end{tabular}

Sumber: Diolah dari berbagai sumber.

Berdasarkan tabel di atas, penulis melihat bahwa meskipun tiap pihak melakukan hate speech, namun sangat sedikit yang melakukan hate speech dengan kategori lainnya karena menggunakan kata-kata yang sifatnya memuji suatu kelompok tertentu. Sebaliknya hate speech banyak dilakukan dengan sarkaseme atau sindiran, dan tidak dengan kata-kata kasar atau bersifat mengancam. Namun data yang di dapatkan pada Instagram lebih sedikit, dibandingkan data Facebook karena Facebook bersifat grup, sedangkan di Instagram data yang di dapatkan bersifat accout pribadi.

\section{Diskusi}

\subsection{Konten Ujaran Kebencian Bernuansa Agama di Media Sosial}

Konten media sosial dapat mempengaruhi opini publik selanjutnya dapat menentukan perilaku politik. Satu dari perdebatan abadi dalam kajian perilaku politik adalah tentang kemampuan politik publik yang menyangkut pengetahuan, pemahaman, dan ketertarikan pada masalah-masalah publik (Kligememan \& Dalton 2011). Penyampaian konten dapat dilakukan melalui berbagai medium seperti internet, televisi, media sosial, bahkan acara langsung seperti konferensi dan pertunjukan panggung. Istilah ini digunakan untuk mengidentifikasi beragam format dan informasi sebagai komponen nilai tambah media. Suatu kejadian yang dimaksud yaitu kontes pada moment politik dalam pemilihan Presiden 2014 dan 2019 yang menjadi fokusnya adalah Joko Widodo, serta dalam pemilihan Gubernur DKI Jakarta pada tahun 2017 yaitu Ahok. Pertama konten Joko Widodo 2014 konten isu Joko Widodo merupakan bagian dari keturunan PKI mulai ketika moment Pilpres 2014, konteks yang dimaksud adalah "PKI" dengan maksud untuk menjatuhkan orang lain. Konten ujaran kebencian ini pada awalnya tersebar di salah satu Tabloid Obor Rakyat (OR), yang menurunkan sebuah tulisan mengenai riwayat calon presiden JokoWidodo pada mei 2014 (dua bulan sebelum pilpres 2014 berlangsung) yang mengatakan bahwa "JokoWidodo adalah PKI" merupakan ungkapan kebencian dengan bentuk isu sara. Dalam konteks ini maksudnya yaitu bahwa JokoWidodo adalah seorang 
Tionghoa yang bernama Oey Hong Liong, dan dia adalah aktivis dari PKI, dan dia disebutsebut juga memiliki nama Baptis: Hubertus Handoko.

Kedua dalam konten yang Ahok pada tahun 2017 menyebutkan bahwa Ahok adalah penista agama, ungkapan kebencian dengan bentuk penistaan agama merupakan ungkapan merendahkan orang lain. Komentar hearter dengan bentuk penistaan yang foto dipunggah Ahok pada tanggal 16 februari 2017, yang mengatakan 'bapak babi mama babi' merupakan ungkapan kebencian dengan bentuk penistaan agama tuturan ini dianggap tidak santun karena penutur dengan sengaja memojokkan lawan. Tuturan ini dianggap tidak santun karena adanya tuturan "Bapak babi mama babi" dalam konteks ini maksud yaitu mengungkapkan bahwa Ahok merupakan keturunan Cina dan beragama Kristen dan babi merupakan hewan yang sering di konsumsi oleh orang yang Non-muslim (tidak beragama Islam) karena hewan itu halal untuk dimakan bagi kaum Non-muslim. Adapun salah satu konten yang ada di Instagram pada tanggal 4 Februari 2017 yang mengatakan "Apa kerena Ahok buat Kalijido seperti lu lansung hormar ama Ahok piker woii, orang yang mengejek Al-Quran tuh gapantesidup di dunia ini bng". Maksudnya dalam tuturan ini adalah "orang yang mengejek Al-Qur'an tidak pantas hidup di dunia"maksud tuturan dalam konteks ini yaitu bahwa Ahok yang telah menghina Al-Quran kitab suci agama Islam tentang surat Al-Maidah ayat 51 itu tidak pantas untuk hidup di dunia.

Ketiga konten Joko Widodo 2019 salah satu kasus dalam konten pilpres adalah polisi menangkap pemilik akun Instagram yang masif menyebarkan berita bohong alias hoaks dan ujaran kebencian yang sarat dengan SARA. Dedi Peasertyo menyampaikan, tersangka berinisial MAM (45) yang dibekuk pada selasa 25 Juni 2019 di komplek Borobudur, jalan Tabrani Ahmad, kota Pontianak, Kalimantan. Tersangka adalah pemilik akun Instagram @rif_opposite yang sangat aktif di Instagram melakukan ungguhan gambar dan vidio hasil kreasi dam modifikasi dirinya sendiri di akun Instagram miliknya.

Adapun konten yang diunggah dalam Instagramnya antara lain konten bernada penghinaan atau pencemaran nama baik, di antaranya: jenderal hijau vs jenderal merah anti-Islam, kiyai Jahanam merusak NU, ingkar janji dan ingkar fatwa, serta paslon 01 sering disandingkan dengan monyet. Sementara untuk konten SARA antara lain, yaitu "ada orang kafir China berani larang syariat Islam poligami, kepolisian biadab, terhadap rakyat, TNI mengamankan rakyat dari amukan anjing-anjing keparat”. Itu salah satu konten yang merupakan ujaran kebencian yang dibuat untuk memprovokasi kita antar warga negara Indonesia.

Sedangkan dalam salah satu konten menyebutkan Joko Widodo adalah seorang komunis, Kristen Cina dan anti Islam. Ungkapan kebencian yang menyatakan Joko Widodo adalah seorang komunis, Kristen Cina merupakan merendahkan orang lain. Salah satu komentar heater dengan bentuk komunis yang diunggah 30 maret 2019 mengatakan "masyarakat bertindak agar tidak ada lagi PKI,Joko Widodo adalah PKI anjeeng" tuturan ini di anggap baik karena memojokkan salah satu lawan. "Joko Widodo PKI amjeng" dalam konteks ini, merujuk pada keturunan keluarga PKI. Isunya merupakan anak dari keturunan Tionghoa atau dari China, sedangkan tuturan "anjeng" merupakan nama bintang yaitu anjing, hewan yang cenderung dipelihara oleh orang non-muslim.

Tuturan itu sangat merendahkan bagi Joko Widodo karena momennya pada saat itu adalah presiden dan mencalonkan diri sebagai calon presiden republik Indonesia pada tahun 2019. Tuturan tersebut termasuk ke dalam kategori ujaran kebencian yang dapat menimbulkan konflik agama dan konflik sosial, baik itu konflik secara individu atau konflik antar individu dengan kolompok maupun antara kelompok dengan kolompok baik dari pihak yang mendukung Joko Widodo maupun dari pihak yang tidak mendukung Joko Widodo.

\subsection{Orientasi Ujaran Kebencian Bernuansa Agama}

Orientasi menurut KBBI adalah peninjauan untuk menentukan sebuah sikap (arah, tempat dan sebagainya) yang tepat dan benar, atau sebuah pandangan yang mendasari pikiran, perhatian, atau kecenderungan. Perilaku politik menurut Edikusuma sebagaimana yang di kutip Solihah (2016) merupakan sebuah tindakan individual atau kelompok dalam aktivitas politik termasuk presepsi, sikap, orientasi, pemberian suara dan lobi. Pengetahuan, pemahaman akan politik berikut proses-proses yang ada di dalamnya tidak terlepas dari lingkungan dimana masyarakat tinggal dan melakukan sosialisasi secara rutin. Dalam konteks Indonesia, budaya politik merupakan realitas yang dianggap paling kuat dan fundamental dalam sistem politik (Ammelia \& Kosandi, 2020; Gatara \& Said, 2007). 
Terlebih bahwa budaya masyarakat Indonesia khususnya budaya antar etnis yang demikian heterogen dan kompleks dengan fragmentasinya menghasilkan heterogenitas etnis dan budaya yang menjadikannya sebagai negara di dunia yang paling plural dengan bahasa paling beragam (Astra, 2014; Hakim, 2020)

Almold dan Verba (2002) sebagaimana dikutip oleh Noor (2014) berpendapat bahwa budaya politik sebagai sikap dan orientasi warga negara terhadap sistem politik dan bagian-bagiannya termasuk sikap kepada peran warga negara di dalamnya, Almold dan Verba melihat bentuk orientasi menjadi orientasi kognitif, orientasi kognitif menyangkut pengetahuan dan kepercayaan kepada sistem politik. Budaya politik partisipan juga merupakan budaya yang intens dan aktif dalam kegiatan politik paling tidak dalam pemilihan (voting) dan memiliki orientasi yang cukup. Budaya masyarakat di orientasi secara nyata dalam semua elemen, proses, sistem dam stuktur politik maupun birokrasi (Gatara \& Said, 2007). Orientasi yang digunakan pada moment politik yang berkaitan dengan agama adalah berkaitan dengan sebuah kepercayaan atau yang kita kenal dengan sebutan sebuah ideologi, maraknya orientasi pada ideologi kepercayaan ini, pada momen politik pemilihan Gubernur DKI Jakarta yaitu Basuki Tharaja Purnama Ahok.

Orientasi yang dikaitkan pada pemilihan DKI Jakarta 2017 sebagai tahun politik yang panas di DKI Jakarta, dalam orientasi ini dikaitkan dengan ideologi agama karena Basuki Tharaja purnama atau Ahok yang pada saat itu dikaitkan isu yang yang berkembang dengan kasus penistaan agama, yang sampai di bawa ke ranah hukum. Ahok mengikuti sidang pembacaan putusan di pengadilan negeri Jakarta Utara di Auditorium Pertanian, Jakarta Selatan, selasa (9/5/2017). Majelis hakim menjatuhkan hukuman pidana 2 tahun penjara. Basuki Tjahaja Purnama dengan kasus penodaan agama, Ahok menjalani proses pilkada DKI Jakarta dengan beban yang lebih besar dibandingkan dengan semua lawannya. Dia harus mengikuti persidangan kasus penodaan agama yang menimpanya. Kasus itu bermula ketika dia melakukan kunjungan kerja ke kepulauan Seribu pada 27 september 2016. Ahok dituduh menodai agama Islam kerena mengutip Al-Maidah Ayat 51 dalam pidatonya.

Sedangkan orientasi yang pada Joko Widodo pada pemilihan pemilihan presiden 2019 adalah orientasi pembangunan, ekonomi dan ideologi, hal tersebut tercemin dari orientasi pemerintahan yang lebuh mengutamakan hasil ketimbang proses. Terlebih, menurut Jeirry, dengan jargon Joko Widodo "Kerja, Kerja, kerja". Joko Widodo memang menyatakan akan melakukan pembangunan sumber daya manusia (SDM). Namun menurut dia, yang terjadi justru pada pembangunan fisik sejak lima tahun yang lalu. Sedangkan orientasi agama yang digunakan adalah masalah ideologis antara pendukung komunisme dan pendukung khilafah serta isu anti Islam dan Partai Komunis Indonesia (PKI) yang dialamatkan kepada calon presiden nomor urut 01. Salah satu hal yang di pandang bagian dari strategi Jokowi untuk tetap berkuasa adalah memasukan KH. Ma'ruf Amin, tokoh Nahdatu Ulama yang saat ini di majelis ulama Indonesia sempat mengeluarkan fatwa yang dipandang meyudutkan salah satu kelompok minoitas sepeti Ahmadiyah atau LGBT, itu adalah salah satu dari cara orientasi ideologi dari Joko Widodo.

\section{Kesimpulan}

Hate speech merupakan salah satu bentuk hate crime yang banyak terjadi di media online (internet), khususnya media sosial. Berkaitan dengan bentuk hate speech, pengguna Facebook cenderung menggunakan sarkasme ketimbang kata-kata caci makian dalam mengekpresikan hate speech. Ujaran kebencian dijadikan salah satu strategi memenangkan kontestasi politik dengan cara penyebaran kampanye yang hitam (black campaign), berita bohong, hoax, dan diskriminasi via media sosial. Hal ini juga didapati di Instagram, yakni menggunakan kata-kata sindiran atau sarkaseme. Data yang ditemukan di Facebook lebih banyak di bandingkan di Instagram, karena Facebook tampak lebih lazim termuat atas berbagai grup, salah satunya yang menjadi rujukan dalam studi ini adalah adalah grup "Prabowo For NKRI" sementara di Instagram salah satu accout pribadi yang di ikuti adalah "azlansyah_alfaruq212".

Tipe dari ujaran kebencian (hate speech) dapat dikategorikan kepada sindiran/sarkasme, hoax, makian, distorsi, cacian, kriritik negatif. Dari data tersebut, juga dapat dilihat bentuk hate speech kedua yang sering disebarkan oleh masyarakat di Facebook dan Instagam adalah status atau komentar yang bersifat kritik negatif. Hal ini menunjukkan bahwa para pengguna Facebook lebih sering memilih bahasa yang paling halus menurut mereka sebagai bukti kekecewaan atau kebencian mereka terhadap suatu 
pihak. Penggunaan sindiran/sarkasme dan kritik negatif salah satunya dipengaruhi adanya regulasi Facebook dan Instagram berkaitan dengan kata-kata yang mengandung kekerasan dan bersifat kasar. Di dalam regulasi itu, Facebook menegaskan pelarangan adanya konten yang menyerang seseorang terkait dengan ras, etnis, agama, gender, orientasi seksual, dan disabilitas. Kecenderungan menggunakan facebook dan instagram didasarkan kepada beberapa hal.

Pertama, Facebook dan Instagram bersifat anonimitas, sehingga para pengguna dapat secara bebas melakukan hate speech terhadap pihak yang tidak dia sukai. Kedua invisibilitas, yang membuat para pengguna tidak terlihat wajah atau lokasi tempat melakukan hate speech. Hal ini juga memengaruhi mengapa sebagian besar pengguna yang menyebarkan hate speech hanya menggunakan tulisan, tanpa foto ataupun video. Ketiga yaitu adanya komunitas, yang menciptakan terjadinya hatespeech didorong adanya trigasi dari salah seorang di dalam komunitas tersebut, dan didukung oleh pengguna lain yang memiliki identitas yang sama dengan orang yang memicu kebencian.

Tipe-tipe ujaran kebencian di Facebook adalah pertama sindiran atau sarkasme, kedua makian, ketiga ancaman, keempat kritik negatif, kelimat distorsi, keenam hoax dan kebohongan, Hasil akhir yang ditemui data sebanyak 765 data, yang terdiri dari 47 status dan 718 komentar yang banyak melakukan tipe dari ujaran kebencian dalam bentuk ujaran kebencian yaitu diskiriminasi dan prasangka buruk. Tipe-tipe ujaran kebencian di instagram adalah: pertama sindiran atau sarkasme. Kedua, makian. Ketiga, kritik negatif. Keempat, lainnya atau tipe pujian. Hasil akhir yang ditemukan sebanyak 72 data yang terdiri dari 5 status dan 67 komentar yang banyak melakukan ujaran kebencian dalam kategori atau tipe sindiran sedangkan data yang paling sedikit ditemui yaitu dalam kategori lainnya. Maksud dari kategori lainnya adalah memuji suatu kelompok atau mendukungnya. Sementara dari segi konten atau konteks adalah pertama konten Jokowi 2014 yang di gambarkan keturunan PKI, konteksnya merupakan keturunan dari Tionghoa. Kedua konten Ahok 2017 bahwa Ahok adalah penista agama serta dalam konteks keturunan Cina yang beragama Kristen. Ketiga konten Jokowi 2019 dimana kontennya bernada penghinaan antara anti Islam dan Kristen Cina.

Orientasi yang digunakan pada momen politik berkaitan dengan agama adalah berkenaan dengan sebuah kepercayaan atau yang kita kenal dengan sebutan ideologi. Maraknya orientasi pada ideologi kepercayaan ini, pada momen politik pemilihan Gubernur DKI Jakarta yaitu Basuki Tharaja Purnama. Orientasi ini dikaitkan dengan ideologi agama karena Ahok saat itu dikaitkan isu kasus penistaan agama, yang kasusnya sampai dibawa ke ranah hukum. Ahok mengikuti sidang pembacaan putusan di pengadilan negeri Jakarta Utara di Auditorium Pertanian Jakarta Selatan, selasa (9/5/2017). Majelis hakim menjatuhkan hukuman pidana 2 tahun Penjara. Basuki Tjahaja Purnama dengan kasus penodaan agama, mengikuti proses kontestasi pilkada DKI Jakarta dengan beban yang lebih besar dibandingkan dengan semua lawannya. Sedangkan orientasi pada Joko Widodo pada pemilihan pilpres 2019 adalah orientasi pembangunan, ekonomi dan ideologi. Hal tersebut tercermin dari orientasi pemerintahan yang lebih mengutamakan hasil ketimbang proses.

\section{Ucapan Terima Kasih}

Penulis sangat berterima kasih kepada semua pihak yang telah menginisasi dan membantu dalam proses publikasi artikel ini.

\section{Konflik Kepentingan}

Penelitian yang dilakukan dalam studi ini adalah menggunakan biaya personal.

\section{Daftar Pustaka}

Ahnaf, M. I., \& Suhadi. (2014). Isu-isu Kunci Ujaran Kebencian (Hate Speech): Implikasi terhadap Gerakan Sosial Membangun Toleransi. Harmoni: Jurnal Multikultural \& Multireligius, 13(3), 153-164.

Ammelia, E., \& Kosandi, M. (2020). Politik Kartel di Tingkat Lokal: Studi Pemilihan Wakil Gubernur Kepulauan Riau Periode Sisa 2016-2021. Indonesian Journal of Religion and Society, 1(2), 138-150. https://doi.org/10.36256/ijrs.v1i2.72

Apriliana, D. (2019). Deretan Kampanye Hitam yang Merujuk pada Jokowi di Pilpres 2019. IDN TIMES.

Astra, I. G. S. (2014). Pluralitas Dan Heterogenitas Dalam Konteks Pembinaan Kesatuan 
Bangsa. Jurnal Kajian Budaya, 10(20), 1-20.

Debora, Y. (2016). Kronologi Kasus Dugaan Penistaan Agama. Tirto.Id.

Fernandes, A. (2019). Politik Identitas dalam Pemilu 2019: Proyeksi dan Efektivitas. In Centre For Strategic And International Studies (Issue 1).

Firdaus, F. (2013). Parade Iklan Politik di Tahun Politik: Polarisasi Penggunaan Iklan Politik Untuk Membangun Citra Menuju Pemilu 2014. Turast: Jurnal Penelitian Dan Pengabdian, 1(1), 81-94.

Gatara, A. A. S., \& Said, M. D. (2007). Sosiologi Politik: Konsep dan Dinamika Perkembangan Kajian. Pustaka Setia.

Hakim, L. D. R. (2020). Grebeg Sudiro dan Representasi Keberagaman di Sudiroprajan, Kota Surakarta. Indonesian Journal of Religion and Society, 2(1), 1-11. https://doi.org/10.36256/ijrs.v2i1.74

Hardiman, F. B. (2017). Kebangkitan Populisme Kanan dalam Negara Hukum Demokratis. Prisma: Jurnal Pemikiran Sosial Ekonomi, 36(Bangkitnya Populisme dan Krisis Demokrasi).

Heinze, E. (2016). Hate Speech and Democratic Citizenship. Faculty of Laws Queen Mary University of London London.

Herdiansah, A. G. (2017). Politisasi Identitas dalam Kompetisi Pemilu di Indonesia Pasca 2014. Jurnal Bawaslu, 3(2), 169-183.

Hernawan, W. (2017). Prasangka Sosial Dalam Pluralitas Keberagamaan Di Kecamatan Cigugur Kabupaten Kuningan Jawa Barat. Sosiohumaniora, 19(1), 77-85. https://doi.org/10.24198/sosiohumaniora.v19i1.9543

Irawan. (2018). Hate Speech di Indonesia: Budaya dan Solusi. Mawa izh: Jurnal Dakwah Dan Pengembangan Sosial Kamanusiaan, 9(1), 1-17. https://doi.org/10.32923/maw.v9i1.712

Maryam, R. (2017). Stereotipe Dan Mitos dalam Penanganan Kasus Kekerasan terhadap Perempuan. Jurnal Lehilasi Indonesia, 14(4), 383-394.

Murdianto, M. (2018). Stereotipe, Prasangka dan Resistensinya (Studi Kasus pada Etnis Madura dan Tionghoa di Indonesia). Qalamuna, 10(2), 137-160.

Noor, F. (2014). Perilaku Politik Pragmatis dalam Kehidupan Politik Kontemporer: Kajian atas Menyurutnya Peran Ideologi Politik. Masyarakat Indonesia, 4O(1), 57-74.

Nurdin, W. (2017). Sebut Foto Ahok Salami Raja Arab Hoax, Jonru Mengaku Khilaf. Tribunnews.Com.

Solihah, R. (2016). Politik Transaksional Dalam Pilkada Serentak Dan Implikasinya Bagi Pemerintahan Daerah Di Indonesia. The POLITICS: Jurnal Magister Ilmu Politik Universitas Hasanuddin, 2(1), 97-109.

Tiurina, S. (2018). Analisis Identitas Status di Facebook Terkait Dengan Hate Speech Terhadap Mantan Gubernur DKI Jakarta (Studi Kasus: Hate Speech di Facebook terhadap Ahok) [Universitas Indonesia]. https://doi.org/10.1063/1.4914609

Umroh, F. (2019). Ujaran Kebencian (Hate Speech) Pada Jejaring Media Sosial. Jurnal Penelitian, Pendidikan Dan Pembelajaran, 15(13), 1-14. 